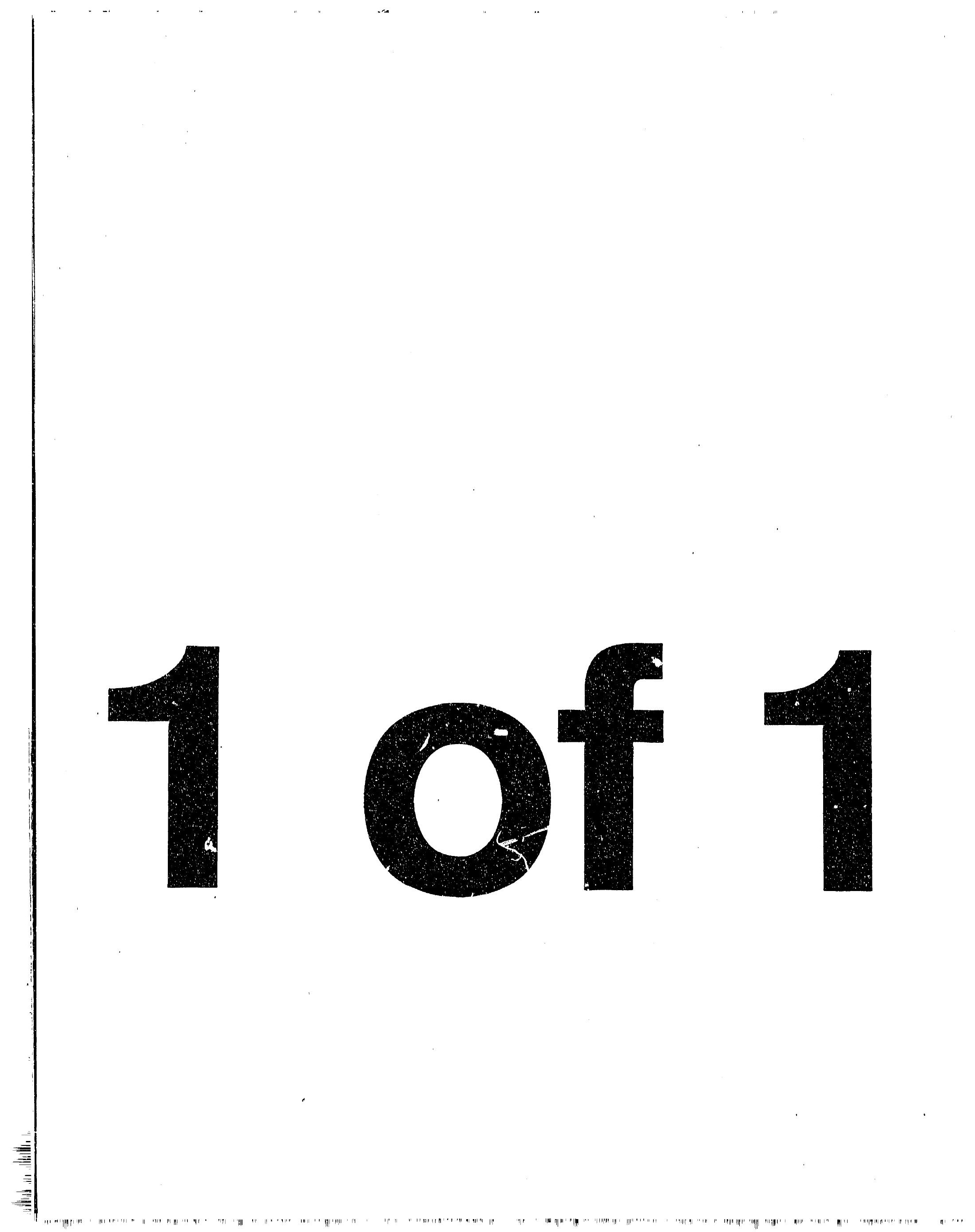




\section{DEVELOPMENT OF CERAMIC COMPOSITE HOT-GAS FILTERS}

\author{
Roddie R. Judkins and David P. Stinton \\ Fossil Energy Program \\ Metals and Ceramics Division \\ Oak Ridge National Laboratory \\ Oak Ridge, Tennessee
}

\author{
Robert G. Smith, Edward M. Fischer, \\ Joseph H. Eaton, Bill L Weaver, J. Lawrence \\ Kahnke, and Douglai J. Pysher
}

\author{
3M Company \\ St. Paul, Minnesota
}

\begin{abstract}
A novel type of hot-gas filter based on a ceramic fiberreinforced ceramic matrix was developed and extended to fullsize, $60-\mathrm{mm}$ OD by 1.5 -meter-long, candle filters. A commercially viable process for producing the filters was developed, and the filiers are undergoing testing and demonstration throughout the world for applications in pressurized fluidized-bed combustion (PFBC) and integrated gasification combined cycle (IGCC) plants. Develspment activities at Oak Ridge National Laboratory (ORNL) and at the $3 \mathrm{M}$ Company, and testing at the Westinghouse Science and Technology Center (STC) are presented. Demonstration tests at the Tidd PFBC are unilerway. Issues identified during the testing and demonstration phases of the development are discussed. Resolution of the issues and the status of commercialization of the filters are described.
\end{abstract}

\section{INTRODUCIION}

The successful development and deployment of several advanced coal-fueled gas turbine technologies depend greatly on the ability to clean fuel or combustion gas streams of particulates prior to these gases being passed through the turbines. These technologies include IGCC, PFBC, and direct coal-fired turbines. Rigid ceramic filters of a variety of designs are either commercially available or under development in programs around the world. Several filter designs are in use or are being developed. The most popular is the candle filter, which resembles a laboratory test tube in having one end closed and a flanged opening at the other.

Rigid ceramic candle filters are currently being developed to remove hot particulates from PFBC and IGCC gas streams being introduced into gas turbines. In these environments the filters will be subjected to nominal temperatures of 600 (IGCC) $10850^{\circ} \mathrm{C}$ (PFBC) at nominal system pressures of about $0.6-1.0$ $\mathrm{MPa}$. However, in several demonstration projects, lower filtration temperatures $\left(250-500^{\circ} \mathrm{C}\right.$ for IGCCs and $700-750^{\circ} \mathrm{C}$ for PFBCs) may be used to demonstrate filtration system concepts. In use, filtration of particulate-laden gas occurs by flow from the outside of the filter to the inside, thus trapping the particles in a cake on the outside of the filter. The filters are repeatedly cleaned by pulses of gases directed from the inside of the filter to the outside. These gas pulses impose thermal shocks on the filters, because the cleaning gas is typically at a much lower temperature than the gas being filtered. In an IGCC system, a reducing atmosphere is obtained and in a PFBC system, an oxidizing atmosphere is obtained. Environments that are corrosive to some ceramic materials can also exist in these systems.

Many different materials - oxides, nonoxides, and mixed - may be used for these candle filters. The most popular oxide ceramics include alumina/mullite, cordierite, aluminosilicate foam/fibers, clay- bonded alumina, fireclay, and continuous fiber ceramic composites produced by chemical vapor infiltration (CVI). Nonoxide ceramics include clay-bonded silicon carbide, sintered silicon nitride, reaction-bonded silicon nitride, recrystallized silicon carbide, and CVI silicon carbide fiberreinforced composite filters. Fabric filter materials include various grades of silica-alumina-boria, alumina-silica, and silicon carbide-silica. Most commercial and near-commercial ceramic filters are made of bonded ceramics. These bonded ceramic filters have proven erratic in performance in use. Breakages have occurred as a result of thermal and mechanical shock.

Managed by Martin Marietta Energy Systems, Inc., under contract DE-AC05-840R21400 with the U.S. Department of Energy.

In a joint effort at ORNL and $3 \mathrm{M}$ Company, a ceramic 


\section{DISCLAIMER}

This report was prepared as an account of work sponsored by an agency of the United States Government. Neither the United States Government nor any agency thereof, nor any of their employees, makes any warranty, express or implied, or assumes any legal liability or responsibility for the accuracy, completeness, or usefulness of any information, apparatus, product, or process disclosed, or represents that its use would not infringe privately owned rights. Reference herein to any specific commercial product, process, or service by trade name, trademark, manufacturer, or otherwise does not necessarily constitute or imply its endorsement, recommendation, or favoring by the United States Government or any agency thereof. The views and opinions of authors expressed herein do not necessarily state or reflect those of the United States Government or any agency thereof. 
composite filter has been developed that could offer a viable alternative to monolithic filters. 1.2 The $3 \mathrm{M}$ Ceramic Composite Filter provides several benefits to a filtering system over conventional monolithic ceramic filters. Some of the benefits that derive from ceramic composites are lighter weight; excellent thermal shock resistance; a balance of toughness and strength; good thermomechanical properties at high temperature; thin filter walls with reduced pressure gradients; and the capability to retrofit into existing filter holders. One of the oft-quoted concerns about ceramic candle filters is their relatively poor resistance to theimal shock. In tests at $3 \mathrm{M}$ to compare the thermal shock tolerance of several varieties of filters, specimens were heated to $1000^{\circ} \mathrm{C}$ and then immersed into water, a very severe test. The best performance was by a first generation ceramic composite filter specimen which retained $27 \%$ of its initial burst strength after eight of these thermal shock cycles as compared to a monolithic filter specimen which degraded to about $18 \%$ of its initial burst strength after only one cycle and thereafter had burst strengths too weak to measure. ${ }^{3}$

\section{PROCESS DEVELOPMENT AT ORNL}

Filter development was begun at ORNL in FY 1986 as an exploratory effort derived from another ORNL project on the development of dense ceramic composites for heat exchange applications. That project, which is funded by the U.S. DOE Office of Fossil Energy Advanced Research and Technology Development (AR\&TD) Materials Program, involves the production of ceramic composites by chemical vapor infiltration (CVI) and deposition of a ceramic matrix into a structural form, hereinafter preform, of ceramic fibers. Figure 1 is a schematic of the CVI process. In the CVI process for producing a composite seramic with a silicon carbide matrix, tricholoromethylsilane is entrained in a stream of hydrogen, transported to the filter preform, and thermally decomposed to deposit a matrix of silicon carbide. As depicted in Fig. 1, controlled heating of the preform results in a controlled and uniform deposition of silicon carbide throughout the filter preform.

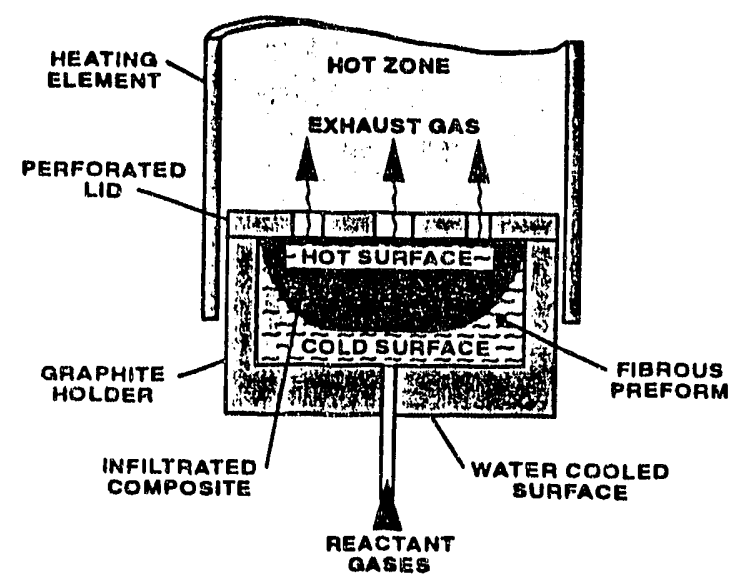

Figure 1. Chemical vapor infiltration process schematic.
Much of the interest in ceramic composite filters derives from their improved strain tolerance as compared to monolithic ceramics. Figure 2 graphically illustrates the improvement in strain tolerance that results from the composite structure. If this strain tolerance can be retained in the filter structures during operation, it would provide a significant advantage over monolithic filters. In this figure, the curve for the monolithic ceramic indicates very little strain tolerance, i.e., a load is applied until stresses exceed the strength of the material and then it breaks catastrophically. The curve for the ceramic composite suggests considerable strain tolerance. This strain tolerance is due to stress relief occurring by several mechanisms. As load is applied, cracking of the matrix may occur with load transfer to the fibers. Load carrying is transferred from matrix to fiber via the fiber-matrix interface. Increased loading may also result in debonding of the fiber-matrix interface. As load is applied, shear stresses exerted on the interface increase until debonding occurs. Thus , cietails of the appearance of stressdeflection curves for composite materials depend on several factors such as fiber loading and strength of the interfacial bond, but Fig. 2 is fairly representative of the general appearance. Discontinuities in the curve correspond to stress and deflection conditions resulting from matrix cracking, debonding, and fiber breaking events as the specimen was loaded.

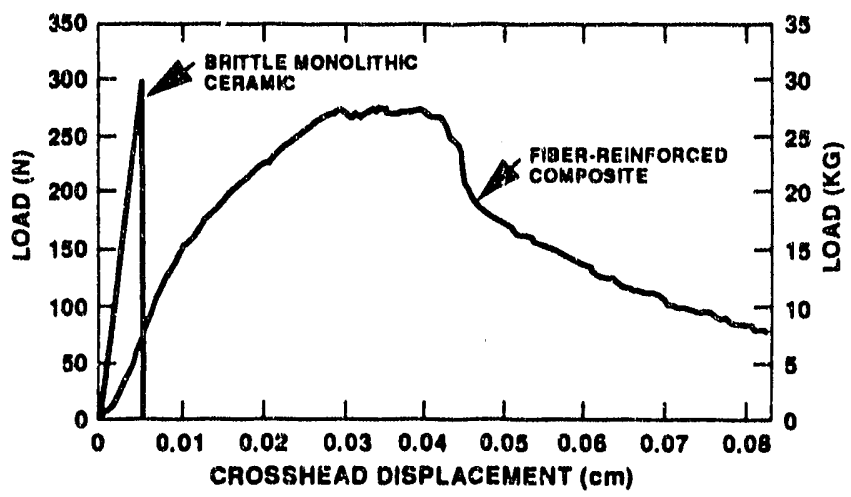

Figure 2. Comparison of the strain tolerance of monolithic and composite ceramics.

Several concepts for ceramic composite filters werc examined at ORNL, and some of these are shown in Fig. 3. Based on initial results, the ORNL filter work was continued under DOE-Morgantown Energy Technology Center (METC) Surface Gasification Materials Program sponsorship in FY 1987, and the AR\&TD Materials Program also continued to support CVI process development and the evaluation of the filters. Tests of filter specimens were conducted at ORNL, Acurex Corporation, and the Coal Research Establishment. (United Kingdom). The ORNL work was continued from FY 1988 through 1991 under METC Advanced Research funding. In FY 1989, the 3M Company was awarded a contract on the AR\&TD Materials Program through competitive bidding to 
scale the ORNL invention (U.S. Patent No. 5,075,160; filed June 13, 1988; issued December 24, 1991) to full-size candle filters.

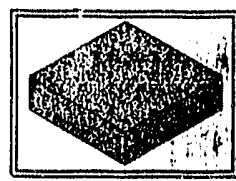

Figure A

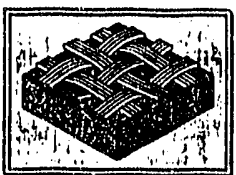

Figure $\mathrm{B}$

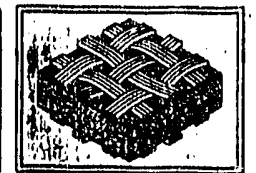

Figure C
Figure 3. Examples of ORNL filter concepts.

To aid the project in addressing relevant issues, a project was conducted by Acurex Corporation and Virginia Polytechnic Institute and State University to assess the causes of failure of ceramic filters. ${ }^{4}$ Several common failure modes were identified. These included thermal and mechanical shock, strength degradation during use, plugging, cracking/breaking at the flange/candle body junction, and binder degradation due to chemical attack. Suspect causes of these failures were improper mounting techniques, tubesheet design, pulse cleaning, candle design, system transients, and corrosive contaminants in gas streams. Information from this project was incorporated into the $3 \mathrm{M}$ project to ensure that the filter developed by $3 \mathrm{M}$ would not suffer from the same deficiencies of other ceramic filters.

Many other tests and investigations of the suspected modes and causes of failures of ceramic candle filters as well as ceramic materials in other applications have been conducted. ${ }^{5.18}$ The results of those investigations were also considered in the present work.

\section{FULLSIZE FILTER DEVELOPMENT AT 3M COMPANY}

In the first quarter of $1993,3 \mathrm{M}$ Company completed the development of its first-generation ceramic composite candle filter. This first-generation filter, shown in Fig. 4, was a filament-wound structure with three plies of Nextel 312 with a filter surface on the exterior of the candle. The filter surface is a barrier layer of random fibers. The binder for the filter is a silicon carbide matrix deposited by chemical vapor deposition (CVD).

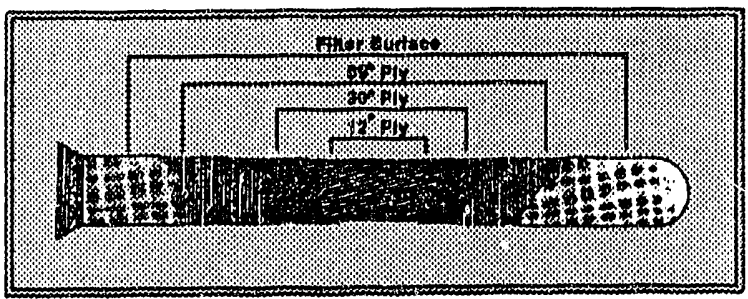

Figure 4. First-generation 3M Company ceramic composite filter.
Two of the first-generation 3M Company filters were tested at the Westinghouse Science and Technology Center (STC) in March 1993. These tests were conducted in a simulated PFBC environment at 815 to $830^{\circ} \mathrm{C}$ for a total of 136.4 operating hours. Ten turbine trip simulation thermal transients were made and the filters withstood these transients without cracking or failure. Filter performance was good and consistent with other ceramic candle filters. Thus, the Westinghouse test demonstrated that a workable filter surface on a strong substrate had been developed. However, the test also revealed a need for improved filter construction. One candle filter experienced patchy cleaning and partial $(\approx 75 \%)$ loss of the filter surface. A need was identified for further work on the CVI bonding of the filter surface to the intermediate layer and substrate, which was suspect during filter fabrication at $3 \mathrm{M}$. Increased reinforcement of the seal flange to permit forming a tighter seal was also determined to be needed. Details of this phase of the filter development are presented in a $3 \mathrm{M}$ Company report. ${ }^{19}$

Improvements in filter construction and fabrication processing were made by $3 \mathrm{M}$. Among the most significant changes were strengthening of the flange seal area; elimination of the filament-wound structure; and the incorporation of an open-braided outer layer to address the problem of sloughing off of the filter surface. The braided structure offers significant economic advantages to filament winding. The resultant structure incorporates a filter surface sandwiched between a tightly braided inner layer and the open-braided outer layer of Nextel fibers. This open-braided outer layer is evident in Fig. 5 , which is a photograph of the $3 \mathrm{M}$ Company Ceramic Composite Filter, Type 203, and a clay-bonded silicon carbide filter.

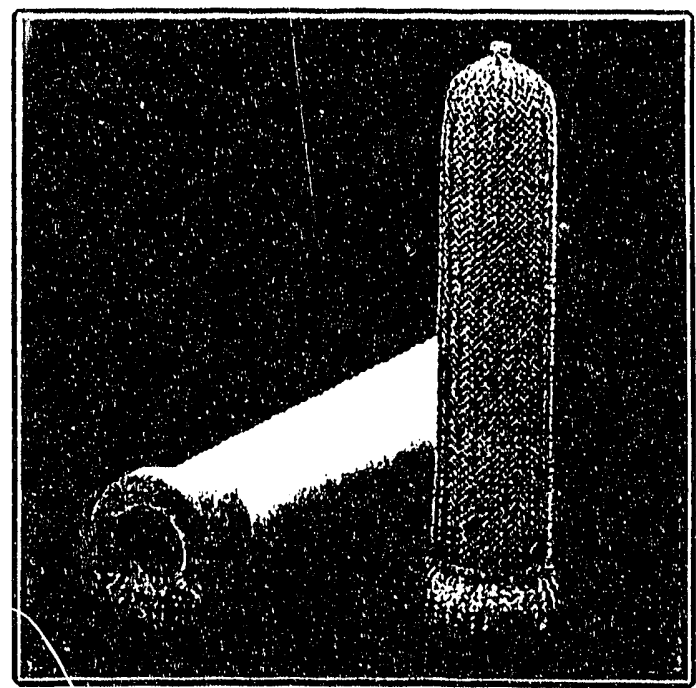

Figure 5. Second-generation $3 \mathrm{M}$ ceramic composite filter and a clay-bonded silicon carbide filter. 


\section{TESTS OF TYPE 203 FILTERS}

Testing of six of the 3M Company's second-generation filters, the type 203 filter, was conducted at Westinghouse STC in December 1993. These filters were tested to measure filter cleanability and operating characteristics under PFBC conditions. The filters were mounted in a standard monolithic candle filter holder. Prior to mounting the filters, the pressure gradient of each was measured at room temperature as a fun on of equivalent face velocity by flowing air into the top of : se filter through a rubber stopper. After mounting the fill $\mathrm{s}$ and closing the test system the filter pressure gradient was dc mined at various face velocities at both ambient terisperature and at operating temperature.

The test was scheduled for 175 hours at a fitter temperature of $815-830^{\circ} \mathrm{C}$ with a system operating pressure of 0.69 to $0.86 \mathrm{MPa}$. Tests were conducted for 172 total operating hours using two lots of ash, first using the "Old Grimethorpe Ash," which is a commonly-used ash obtained from the Grimethorpe (United Kingdom) PFBC, and then a more difficult to filter ash called "Red Grimethorpe Ash." The inlet gas flow had an ash concentration of $2000 \mathrm{ppm}$. The air flow rate was $499 \mathrm{kgm} / \mathrm{h}$ with a filter face velocity of $3.55 \mathrm{~cm} / \mathrm{sec}$. Cleaning pulses were triggered when the differential pressure from ash cake buildup reached 7.5 to $9.5 \mathrm{kPa}$. The cleaning pulses were of 0.4 second duration from a pressure tank of 2.1 $\mathrm{MPa}$. The tests were run on a 12 -hours per day schedule for the first three days and then run 24 hours per day until the test was finished. Samples of ash were taken from the clean side of the chamber through high efficiency filter paper at various times throughout the filter test to calculate the clean side ash concentration.

During the changeover from the Old Grimethorpe Ash to the Red Grimethorpe Ash, 14 turbine trip simulations were run over a 12 hour period to subject the filters to the thermal shocks typical of a system trip or fast shutdown. These simulations involved shutting off the gas burner and decreasing the air flow to zero in steps to cause rapid cooling of the filters. The air flow and gas burner were then restarted to rapidly bring the temperature back to operating conditions. ${ }^{20}$

The individual ceramic composite filter pressure gradients as a function of face velocity were $0.199 \mathrm{kPa}$, which was about one-half that of a typical monolithic ceramic filter element. The pressure gradient measurements in the test system were $1.9 \mathrm{kPa}$ at a face velocity of $3.3 \mathrm{~cm} / \mathrm{sec}$ at ambient temperature and 2.5 $\mathrm{kPa}$ at a face velocity of $3.5 \mathrm{~cm} / \mathrm{sec}$ at $815^{\circ} \mathrm{C}$. The system measurements are higher than for the individual filters because they include the total test system of filters, holders, plenum, and pulse system.

The filters were pulse cleaned approximately every two and one-third hours while using the Old Grimethorpe Ash for a total of 49 pulses. For the Red Grimethorpe Ash, the filters were pulse cleaned every one and one-third hours for a total of 30 pulses. Thirty-four clean side ash concentration samples were taken during the 172 hours of testing. The sampling times ranged from 30 minutes to 5 hours for a total of about 100 hours of sampling. The average (mean) clean side ash concentration was $2.5 \mathrm{ppm}$. All samples save one indicated an ash concentration of less than $4 \mathrm{ppm}$ (see Fig. 6). No filter seal : "age was observed during the sampling. Acceptable levels, l.e., turbine tolerance levels for erosion considerations, of ash concentration are about $10 \mathrm{ppm}$ for $1 \mu \mathrm{m}$ particle size and about $1 \mathrm{ppm}$ for $10 \mu \mathrm{m}$ particle size; the type 203 filters appear to have met these criteria.

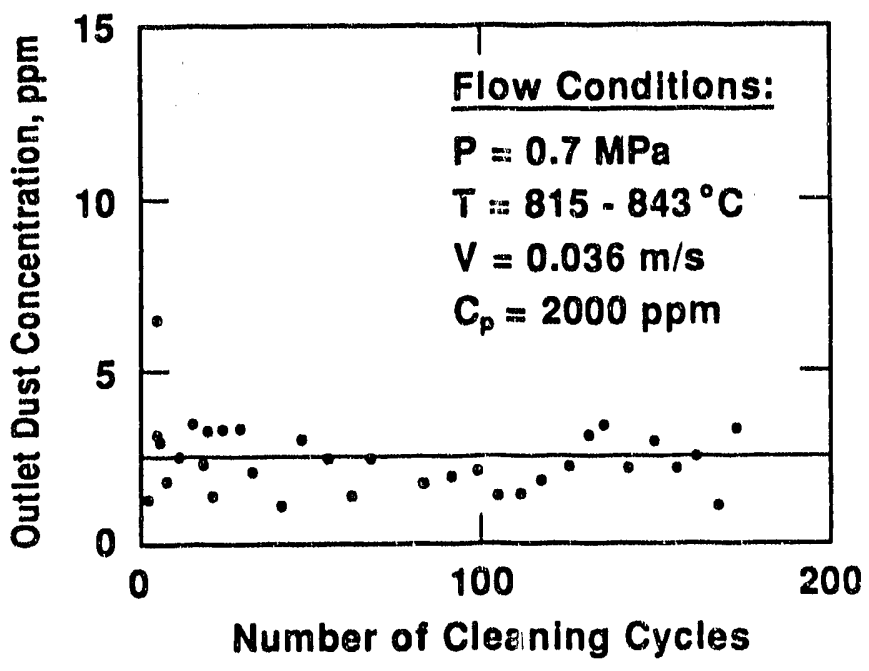

Figure 6. Filter test outlet ash concentration.

Relative filter permeability ${ }_{i}$ the ratio of filter permeability at any time to the initial filter permeability, is a good indicator of filter performance. Figure 7 presents the results of calculations of relative filter permeability of the type 203 filters. The figure indicates that the filters have become well conditioned after about 50 cleaning cycles and that relative filter permeability has become constant. Under this condition, ash buildup during filtering is constant and ash removal is consistent during the cleaning cycles. After testing, the filters had a uniform, about $1.5 \mathrm{~mm}$ thick, ash coating on the filter surfaces, which is indicative of a properly functioning set of filters. No irregularities were observed on the thin ash coating. Gaskets in the mounting system were clean and intact.

The type 203 filters met or exceeded all performance criteria for a successful test. They proved to be more durable than the previous design, and none of the filter surfaces came off during the tests. Dust removal efficiencies exceeded $99.8 \%$ with $<4$ ppm dust in the exit gas from the filters. The filters 
reached stable, conditioned permeability after 50 cleaning cycles. Permeance values and trends were consistent with clay-bonded filters. Acceptable cleaning of the filters was maintained using up to 2.1 MPa pulses of cleaning gas. Mounting and gasketing maintained dust seals without apparent leakage. Post-test examination indicated significant strength retention. There was no damage (breakage, cracks, distortion, etc.) apparent to the $3 \mathrm{M}$ filters as a result of the test.

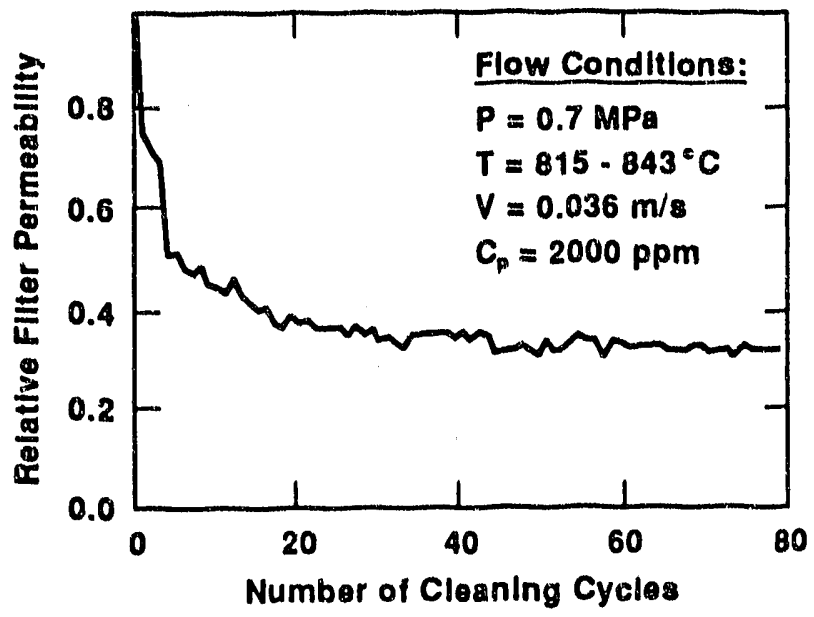

Figure 7. Relative filter permeability of the $3 \mathrm{M}$ Ceramic Composite Filters

\section{TESTS AT THE TIDD PFBC DEMONSTRATION PROJECT}

In August 1994, three type 203 filters were installed in the filter vessel at the Tidd PFBC Demonstration Project (Tidd) for testing. Tidd is a $70 \mathrm{MWe}$ PFBC demonstration plant in Brilliant, Ohio. The demonstration is part of the DOE's Clean Coal Technology Program. At Tidd, a small fraction of the process gas stream, i.e., a slipstream, is diverted to the filter system, which can accommodate up to 384 candle filters. In this test at Tidd, performance of the $3 \mathrm{M}$ filters was good and demonstrated their ability to function in this environment for over 1600 hours. Although data analysis for this test is incomplete, and thus the conclusions we have drawn are preliminary, the following observations may be pertinent and useful.

The Tidd demonstration was extremely useful in identifying issues related to the type 203 filters. Two of the three filters were broken at some time during the demonstration run. Although the exact time of breakage was not established, and we believe cannot be established unequivocally, they appear to have functioned for over 1000 hours. The breaks in the candle filters occurred at the top of the filters just below the holder. Since only the flange areas of the broken filters were salvaged after the demonstration, actual causes of the failures also cannot be established unequivocally. We have speculated that the filters were broken as a result of ash buildup and bridging. A phenomenon has occurred in the ridd filter system resulting in filter breakage that appears to result from "bending forces from ash bridging from the inner candles to the outer candles. ${ }^{\text {1121 }}$ During this test run, the inner rows of candles were removed from the top and middle plenums. Observations at the plant suggested that the ash bridging phenomenon appeared to begin with ash building up on the dust sheds and bridging across to the bottoms of the inner candles. By removing the inner rows of candles, it had been hoped that the problem would be eliminated. Although data and data analysis available at this time are insufficient to confirm that similar bending forces were operative in breakage of the type 203 filters, that failure mechanism is a possibility. Based on this possibility and simulation tests at 3M Company laboratories in which similar breakage has been demonstrated, certain changes in the mounting devices used for the type 203 filters were made. Subsequent laboratory simulation tests using the modified mounting devices indicated that the modifications were effective in preventing breakage. If ash buildup and bridging were the causal factors in the breakage of the two filters in the Tidd demonstration, these modifications should prove to be beneficial.

Our conclusion from the Tidd demonstration and analysis of the filter that performed well for over 1600 hours is that the type 203 filter concept has excellent potential for application in PFBC systems. It is an effective and efficient filter; it experienced no apparent chemical deterioration; it retained a significant percentage of as-manufactured strength after exposure; and no inherent problems with the filter structure were identified.

When the $3 \mathrm{M}$ filters had all apparently performed well for up to 1000 hours, plans were made for an additional demonstration at Tidd which included about 50-60 type 203 filters. Because of the breakage of the two filters and the inability to unequivocally determine the cause of the breakage, plans were modified to include only ten of the type 203 lilters in this subsequent demonstration. In the time frame alvailable, it was not possible to make corrections with a high degree of confidence of preventing additional breakage, and plant operators were concerned about filter breakage and its effect on operations. These considerations notwithstanding, the ten type 203 filters were installed at the Tidd plant in December 1994. In this test, the modified mounting devices are being used. These modified devices were developed by $3 \mathrm{M}$, and their efficacy has been demonstrated in laboratory tests at 3M. In addition to improvements in the candle filter mounting harciware, $3 \mathrm{M}$ is also working on design changes to the filters that will further strengthen the flange area and improve the performance of the filter at the closed end. These design modifications were not made in time to be incorporated into the filters used in this second Tidd Plant test. This test at Tidd i: expected to continue until March 1995. 


\section{CONCLUSIONS}

The 3M Company ceramic composite filters have performed well in PFBC simulation tests at Westinghouse STC. They have demonstrated the ability to function well for over 1600 hours in the Tidd PFBC. Additional in-plant tests at the Tidd PFBC Demonstration Project are in progress to identify any additional issues and to demonstrate the adequacy of these filters in PFBC systems. Both the simulation tests and the plant tests are providing invaluable data for the use of these filters. These and other tests and demonstrations of the composite filters should provide further evidence of the efficacy of these filters. Each step in the development process has resulted in valuable insights into the development of superior filters. Additional tests are needed in other operating PFBCs and in IGCCs. The type 203 filters have now been provided for testing in several facilities worldwide, including advanced PFBC and IGCC plants.

The 3M Company is commercializing the type 203 filter. Design modifications to the filter construction are being made based on evaluation of results of tests at Westinghouse STC and at the Tidd PFBC Demonstration Project. A commercialiy viable process for producing the filters has been developed and demonstrated. The success of this testing and demonstration phase is vital to this novel filter concept, which we believe will offer a viable lightweight composite filter alternative for PFBC and IGCC applications.

This project provides an excellent example of cooperation between the Department of Energy-Fossil Energy AR\&TD Materials Program, Coal Technology Programs, and industry. It is a most successful example of technology transfer from a national laboratory to the industrial sector. This project also confirms the validity of the research and development (R\&D) approach which involved good technical assessments of requirements and a disciplined approach to the $R \& D$ needed to satisfy those requirements.

\section{ACKNOWLEDGEMENTS}

The authors gratefully acknowledge the assistance of Richard A. Dennis of DOE-METC, Thomas E. Lippert of Westinghouse STC, and Michael J. Mudd of Ohio Power Company in providing the opportunity to perform the tests at the Tidd plant.

\section{REFERENCES}

1. R. R. Judkins, D. P. Stinton, R. G. Smith, and E. M. Fischer, "Ceramic Fiber Ceramic Matrix Filter Development, pp. 145-51 in Proceedings of the Coal-Fired Power Systems 94 .. Advances in IGCC and PFBC Review Meetisig, DOE/METC-94/1008, Vol. 1 (DE94012252), U.S. Department of Energy, Morgantown, WV, June
1994.

2. D. P. Stinton, R. A. Lowden, and R. Chang, "Fabrication of Fiber-Reinforced Hot-Gas Filters by CVD Techniques," Ceram. Eng. Sci. Proc., 9(9-10), pp. 1233-44 (1988).

3. L. R. White and T. M. Kafka, Fabrication of CommercialScale Fiber-Reinforced Hot-Gas Filters by Chemical Vapor Deposition, ORNL/Sub/89SB482/01, 3M Company, St. Paul, MN, November 1992.

4. J. Sawyer, Assessment of the Causes of Failure of Ceramic Filters for Hot-Gas Cleanup in Fossil Energy Systems and Determination of Materials Research and Development Needs, ORNL/Sub/86-57964/01, Acurex Corporation, Mountain View, CA, January 31, 1989.

5. R. Clark, et al., "Some Recent Experiences with the EPRI Hot-Gas Rigid Ceramic Filter at Grimethorpe PFBC Establishment," pp. 1251-58 in Proceedings of the 12th International Conference on Fluidized-Bed Combustion, American Society of Mechanical Engineers, New York, 1993.

6. K. R. Valentino, et al., "Durability Testing of Ceramic Candle Filters in PFBC Environments," pp. 1375-83 in Proceedings of the 12th International Conference on Fluidized-Bed Combustion, American Socicty of Mechanical Engineers, New York, 1993.

7. R. E. Tressler, "High-Temperature Stability of Non-Oxide Structural Ceramics," MRS Bull., XVIII(9), 58-63 (1993).

8. M. A. Alvin, J. E. Lane, and T. E. Lippert, ThermalChemical Degradation of Ceramic Cross-Flow Filter Materials-Phase 1, DOE/MC/25034-2967, Westinghouse Electric Corporation Science and Technology Center, November 1989.

9. N. S. Jacobson, "Corrosion of Silicon-Based Ceramics in Combustion Environments," J. Am. Ceram. Soc. 76(1), 328 (1993).

10. N. S. Jacobson and J. L. Smialek, "Hot Corrosion of Sintered $\alpha$-SiC at $1000^{\circ} \mathrm{C}, " J$. Ain. Ceram. Soc. 68(8) $432-39$ (1985).

11. J. L. Smialek and N. S. Jacobson, "Mechanism of Strength Degradation for Hot Corrosion of $\alpha-S i C$, J. Am. Ceram. Soc. 69(10), 741-52 (1986).

12. D. S. Fox and J. L. Smia!ek, "Burner Rig Hot Corrosion of Silicon Carbide and Silicon Nitride," J. Am Ceram. Soc. 73(2), 303-11 (1990). 
13. D. S. Fox, N. S. Jacobson, and J. L. Smialek, "Hot Corrosion of Silicon Carbide and Silicon Nitride at $1000^{\circ} \mathrm{C}, "$ in Corrosion and Corrosive Degradation of Ceramics, ed. R. E. Tressler, and M. McNallan, American Ceramic Society, Westerville, Ohio, 1990 [also Ceram. Trans. 10, $227-49$ (February 1990)].

14. M. A. Alvin, et al., "Evaluation of Ceramic Filter Material, Selection for Application," presented at the Coal-Fired Power Systems 93/Advances in IGCC and PFBC Contractor's Review Meeting, Morgantown, WV, 1993.

15. M. A. Alvin, et al., Degradation of Cross-Flow Filter Material,DOE/METC-90/6110, DOE Morgantown Energy Technology Center, Morgantown, W. Va., March 1990.

16. J. Sawyer, R. J. Vass, N. R. Brown, and J. J. Brown, Corrosion and Degradation of Ceramic Particulate Fillers in Direct Coal-Fired Turbine Applications, ASME Paper 90-GT-347, American Society of Mechanical Engineers, New York, June 1990.

17. H. W. Carpenter, "SiC Tubes Exhibit Excellent Performance in Fluidized-Bed Heat Exchanger Tests, ${ }^{\text {" pp. }}$ 14 in Materials \& Components in Fossil Energy Applications, DOE/FE-0054/54, U.S. DOE, Washington, D. C., Feb. 1, 1985.

18. J. Stringer, "Ceramic Filter Experience at the Grimethorpe PFBC," presentation without publication at the 36th ASME International Gas Turbine and Aeroengine Congress and Exposition, Brussels, Belgium, June 12, 1990.

19. R. G. Smith, J. H. Eaton, and M. A. Leitheiser, Fabrication of Full-Scale Fiber Reinforced Hot-Gas Filters by Chemical Vapor Deposition, ORNL/Sub/89-SB482C/02, 3M Company, Si. Paul, MN, April 1994.

20. R. G. Smith, J. H. Eaton, and M. A. Leitheiser, Full-Scale Fiber-Reinforced Hot-Gas Filter Testing Under Tasks 9 and 10, ORNL/Sub/89-SB482C/04, 3M Company, St. Paul, MN, September 1994.

21. M. J. Mudd, J. D. Hoffman, and R. A. Dennis, "Tidd PFBC Hot Gas Filter Operating Experience: July 1993 April 1994," pp. 519-34 in Proceedings of the Coal-Fired Power Systems 94 .. Advances in IGCC and PFBC Review Meeting, DOE/METC-94/1008, Vol. 1 (DE94012,252), U.S. Department of 'argy, Morgantown, WV, June 1994. 

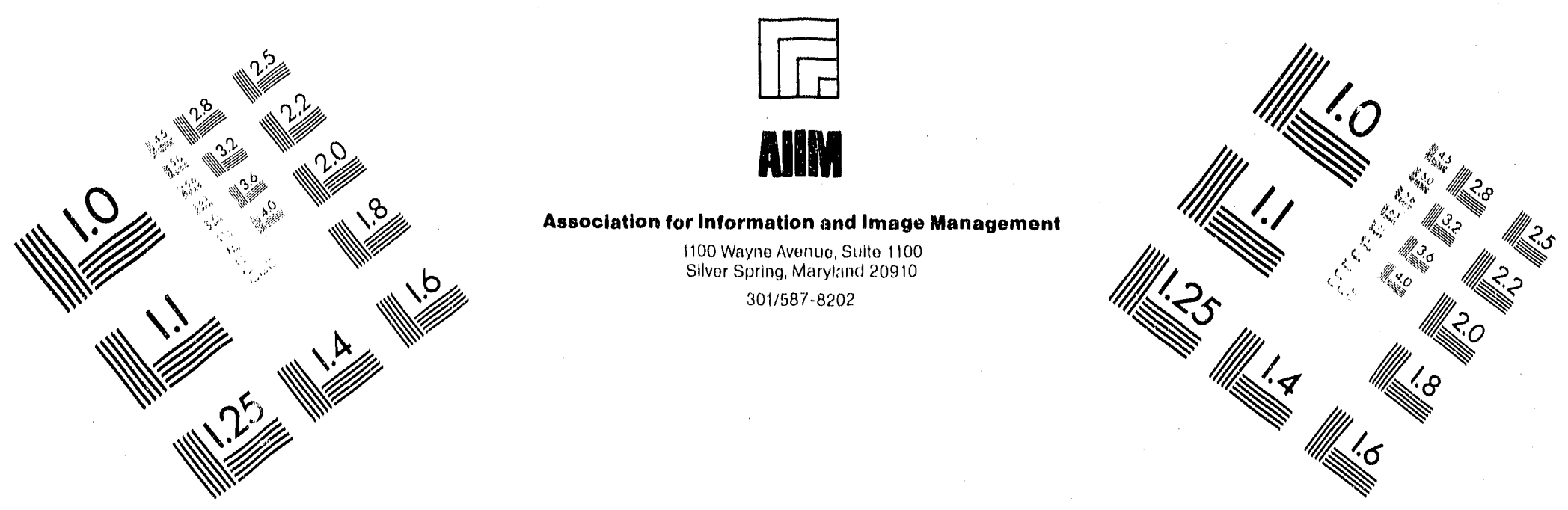

\section{Centimeter}

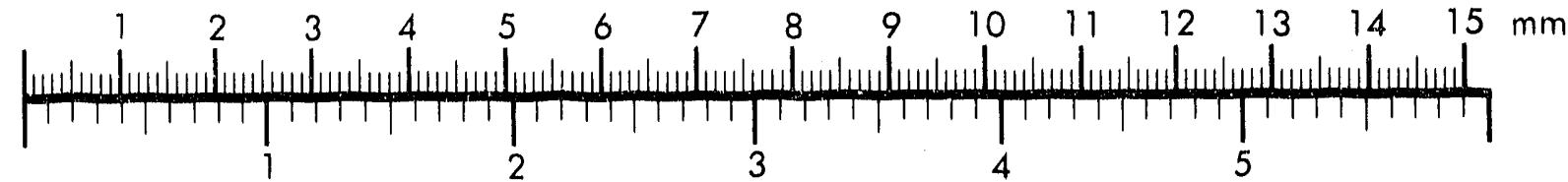
Inches
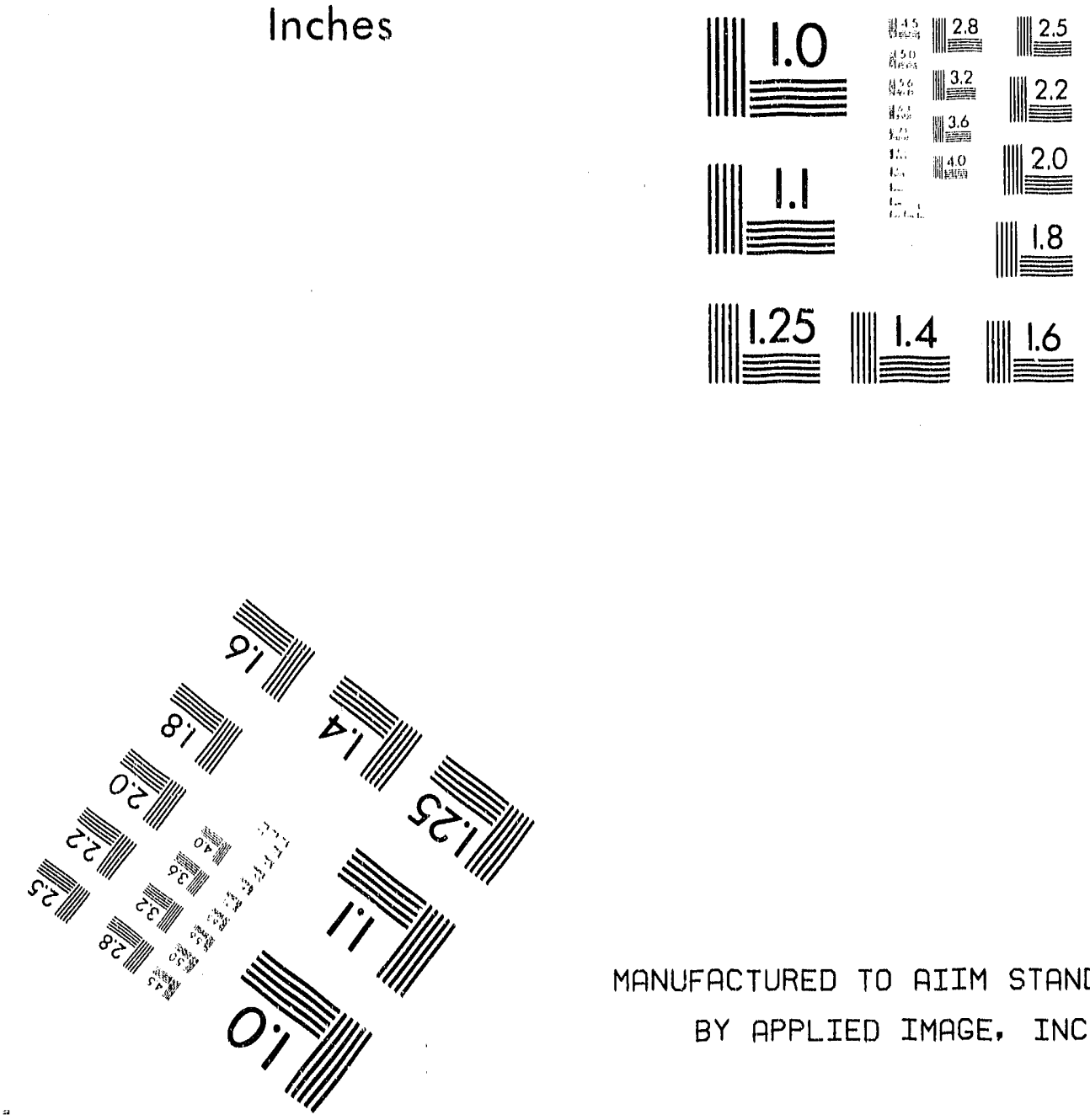

MANUFACTURED TO AIIM STANDARDS

BY APPLIED IMAGE, INC.

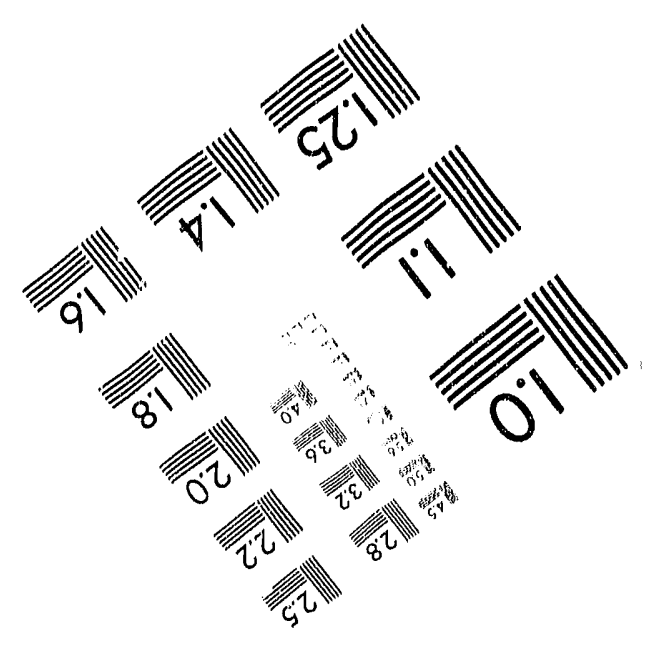




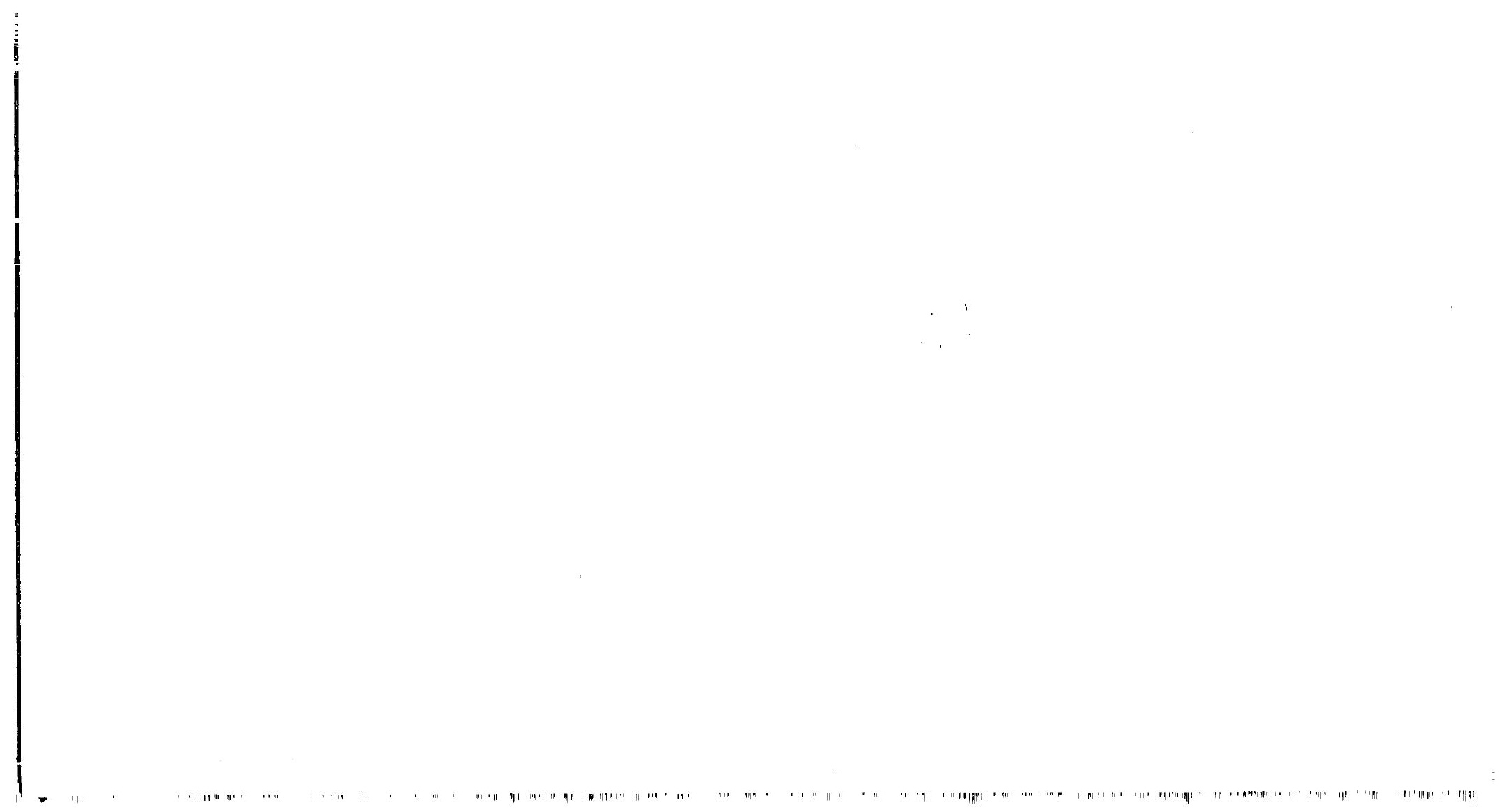



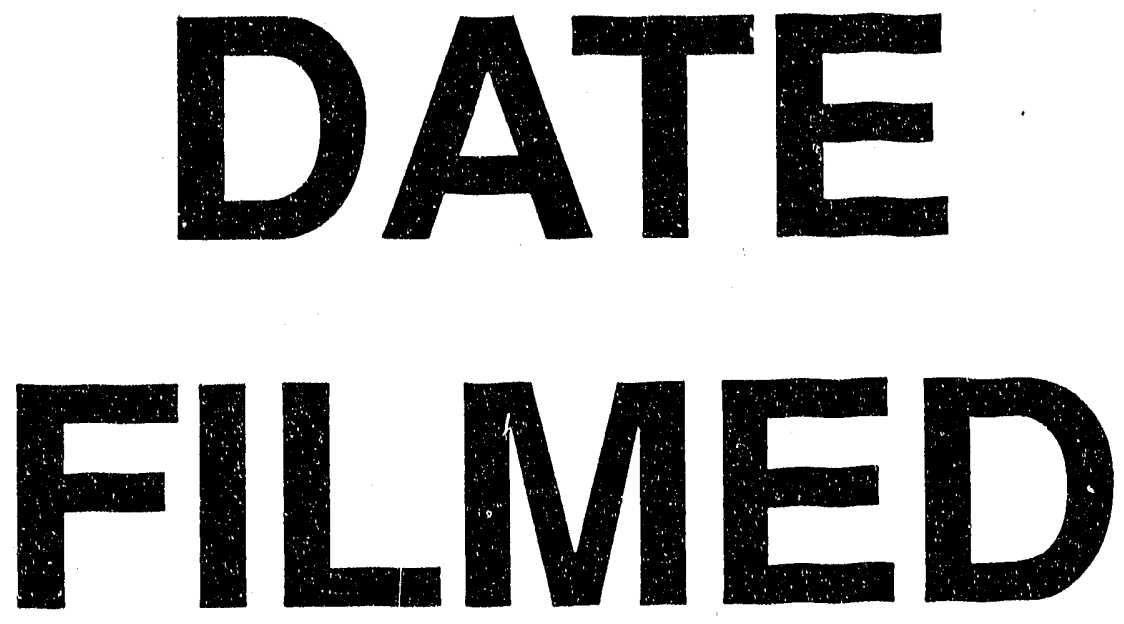

$6 / 22 / 95$
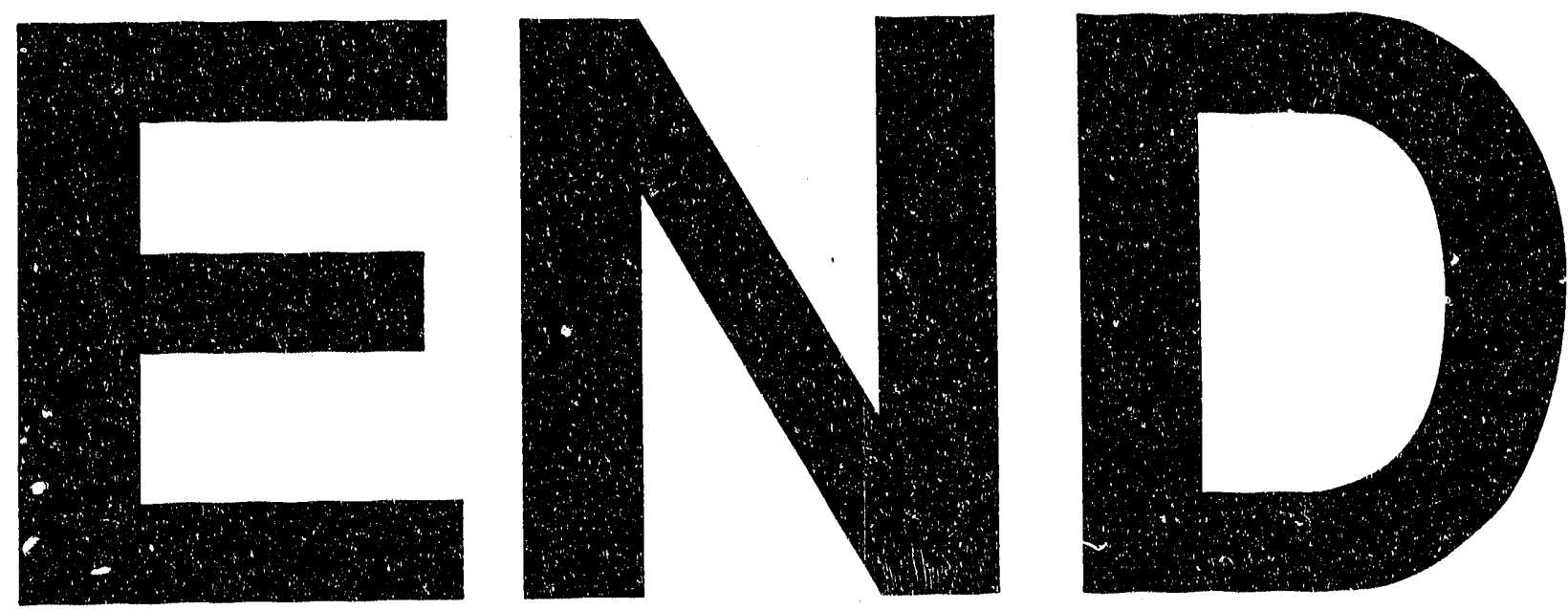